\title{
16p11.2 microdeletion syndrome: a case report
}

D. Dell'Edera ${ }^{1 *}$, C. Dilucca ${ }^{2}$, A. Allegretti ${ }^{1}$, F. Simone ${ }^{1}$, M. G. Lupo ${ }^{3}$, C. Liccese ${ }^{1}$ and R. Davanzo ${ }^{2}$

\begin{abstract}
Background: The recurrent $\sim 600 \mathrm{~kb} 16 \mathrm{p} 11.2$ microdeletion is among the most commonly known genetic etiologies of autism spectrum disorder, overweightness, and related neurodevelopmental disorders.

Case presentation: Our patient is a 2-year-old white girl from the first pregnancy of a non-consanguineous healthy young white couple (father 33-years old and mother 29-years old). Our patient and her parents' DNA were analyzed by comparative genomic hybridization-array platform. Comparative genomic hybridization-array analysis highlighted a $600 \mathrm{~kb}$ deletion in 16p11.2 region. It has a segregant nature, since it was found in the mother and in her 2-year-old daughter. The microdeletion was confirmed by fluorescence in situ hybridization analysis.

Conclusions: The presented clinical case is worthy of note since the observed microdeletion is often associated with a clinical phenotype tending to overweightness, but the proband (female) was hospitalized due to poor height and weight development, and anorexia. Moreover, the segregant nature of the observed genomic abnormality has to be noted, as well as the phenotypic variability between the mother and daughter. The case described here enriches the phenotypical spectrum linked to the 16p11.2 microdeletion. For these reasons, in the presence of a suspected genetic pathology it is fundamental to study the proband from the clinical point of view, to extend the clinical observation to the parents, and to provide a good family anamnesis. In this way, it is possible to reveal the presence of a familial genetic pathology whose phenotypical outcomes can be highly variable among the members of a family.
\end{abstract}

Keywords: Developmental delay, Intellectual disability, CGH-array, Submicroscopic chromosomal changes, 16 p11.2 microdeletion syndrome

\section{Background}

16p11.2 microdeletion syndrome, Online Mendelian Inheritance in Man (OMIM) \#611913, is a rare genetic disorder. There are different categories, or designations, used to describe 16p11.2 deletions based on the location and amount of genetic material deleted. In general, people with a $16 \mathrm{p} 11.2$ microdeletion belong to one of three groups (Fig. 1):

Group 1 Typical microdeletion of a $\sim 600 \mathrm{~kb}$ region containing 29 genes [1]. This deletion has a population prevalence of approximately $1 / 2000$ [2] and reaches $0.5 \%$ in autism spectrum disorders (ASD) [3-7]. It is one of the most commonly known single locus

\footnotetext{
* Correspondence: domenicodelledera68@gmail.com

'Unit of Cytogenetic and Molecular Genetics, "Madonna delle Grazie"

Hospital, 75100 Matera, Italy

Full list of author information is available at the end of the article
}

etiologies of neurodevelopmental disorders and ASD [8]. We and others have demonstrated that this deletion predisposes to a highly penetrant form of obesity with a 43 -fold increased risk of developing morbid obesity [9].

Group 2a/2b has deletions that do not overlap with Group 1 and are closer to the end of chromosome 16; this is called the "distal" 16p11.2 region.

Group 3 has larger deletions that encompass all of the genetic material missing in group 1 and group 2 .

This deletion can happen in a couple of different ways. It can be de novo, meaning that the deletion is brand new in the family. Most often, 16p11.2 deletions are de novo; various studies have found that close to $75 \%$ of children (three out of four) with a 16p11.2 deletion did not inherit it from their mother or father. However, in some families, the deletion is inherited; meaning that 


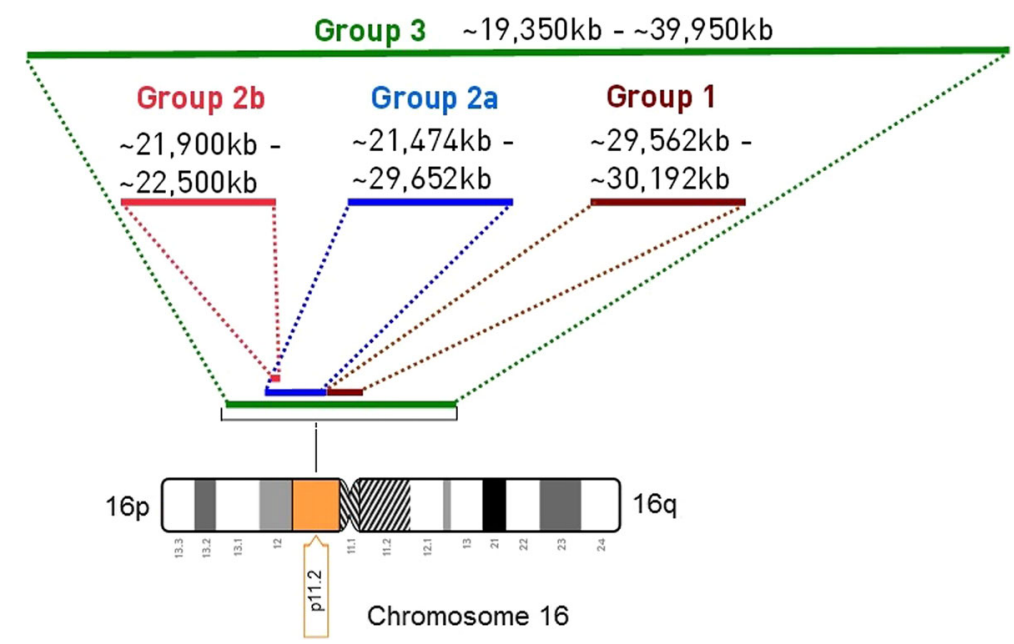

Fig. 1 The 16p11.2 microdeletion is grouped into three groups (explanation in the text)

either the mother or the father also has the 16p11.2 deletion and has passed it to his or her children. If a parent of a child with a 16p11.2 deletion is found to have the deletion as well, there is a probability of $50 \%$ that his or her other children will have the same deletion.

The 16p11.2 microdeletion has been found in nearly 1:100 people with autism, in nearly $1: 1000$ people with a language or psychiatric disorder, and in nearly $3: 10,000$ people in the general population $[10,11]$.

Since a 16p11.2 deletion can be passed down from parents to their children, other family members can be examined to see if they carry the same deletion. If identified subjects with deletion $16 \mathrm{p} 11.2$, for preventive purposes, it is useful to propose prenatal diagnosis.

The phenotypic spectrum associated with the 16p11.2 microdeletion includes ASD, mild mental retardation (MR)/developmental delay (DD) and/or possibly other primary psychiatric disorders. The microdeletions are more likely to be penetrant and to be associated with nonspecific major or minor dysmorphism. There are probands with deletion-positive ASD with a less severe phenotype than siblings with deletion-negative ASD underscoring the significant phenotypic heterogeneity $[12,13]$.

In this work we report a case of a patient who was hypothetically diagnosed with: RAS/MAPK syndromes, Noonan syndrome, or Wolf-Hirschhorn syndrome. Comparative genomic hybridization (CGH)-array analysis has instead found $\mathrm{a} \sim 600 \mathrm{~kb}$ microdeletion lying on the short arm of chromosome 16p11.2. This genomic condition is associated with the "16p11.2 microdeletion syndrome."

The presented case is worthy of note because the observed microdeletion is almost always associated with a clinical phenotype tending to overweightness [14-16], but the proband has been hospitalized because of poor height and weight development, and anorexia. Moreover, both the segregating behavior of the genomic abnormality and the phenotypical variability between the proband and her mother have to be underlined. This is the first report of this kind in the literature.

\section{Case presentation}

Our patient is a 2-year-old white girl born at 39th week of pregnancy through caesarean section to nonconsanguineous Italian parents. The proband's mother is obese and suffers from mild MR and minor dysmorphism.

Her growth parameters at birth were in the normal ranges (weight $3.3 \mathrm{~kg}$ and length $46 \mathrm{~cm}$ ). Apgar scores were $6 / 8 / 9$. The newborn presented dysmorphic signs, which is the reason why genetic screening was performed when she was 18-months old; the genetic screening enabled us to hypothesize three pathologies: RASopathy (that is, pathologies caused by mutations on genes codifying for RAS proteins), Noonan syndrome, and Wolf-Hirschhorn syndrome. At the age of 2 years she was hospitalized at Unit of Neonatology and Pediatrics of Matera, because of poor height and weight development, and anorexia. After medical examination, the girl appeared slightly dehydrated, presented a weight of 5,910 kg and an height of $67 \mathrm{~cm}$, a cranial circumference of $47 \mathrm{~cm}$.

Clinical observation revealed the following: brachycephalic face with a prominent forehead and frontal bossing, slight midface hypoplasia, hypertelorism (interpupillary distance of $2.9 \mathrm{~cm}$ ); with mildly downslanting palpebral fissures, synophrys, small nose with anteverted nostrils and deep-set nasal root, mild prognathism, deep-set posterior rotated ears, full cheeks, and prominent philtrum. She held her mouth mostly opened with a cupid bowed upper lip, full lower lip, and a slightly protruding tongue. 
To better explicate the causes underlying the above described health state, the following instrumental investigations were performed:

- Brain ultrasound: the structures of the median line are on the axis. Normal ventricular morphovolumetry. Modest non-homogeneous of the cerebral parenchyma most pronounced in the periventricular region. Hyperechogenicity of streaked thalamus arteries.

- Renal ultrasound: left kidney renal pielectasia or pyelectasis with "ballooned" aspect of pelvis as of suspected joint pathy. Notes: useful scintigraphic evaluation.

- Scintigraphy: left calico-pyelic stasis, a little responsive to diuretic and orthostasis. Conserved parenchymal functionality but asymmetric, leading to a reduction in left kidney functionality.

- Rachis magnetic resonance imaging (MRI): reported fusion of D4 to D5 and D9 to D10 vertebral bodies. Accentuation of proximal kyphosis with a tendency to reverse dorsal distal portion.
Cervical hypolordosis. Conserved posterior metameric alignment.

- Doppler color echocardiography: normal atriumventricular connection of large vessels. Normal morphovolumetry of cardiac chambers. Patent foramen ovale. Slight pericardial effusion. Discrete thinning of the interventricular septum.

Parameters from routine blood tests and biochemical screenings for metabolic disorders were in the expected ranges. The karyotypes performed for the proband and her parents were normal. Before proceeding with biomolecular investigations as suggested by the geneticist, the pediatrician requested a genomic study by means of $\mathrm{CGH}$ array in order to exclude an eventual genomic pathology.

A CGH array highlighted a 597,84 microdeletion within the short arm of chromosome 16 (16p11.2). Based on the dimension of the deleted genomic fragment, 16p11.2 microdeletion syndrome is part of the first group (Fig. 2).

The microdeleted chromosomic region (29,592,75130,190,593) contains the following OMIM genes: ALDOA,

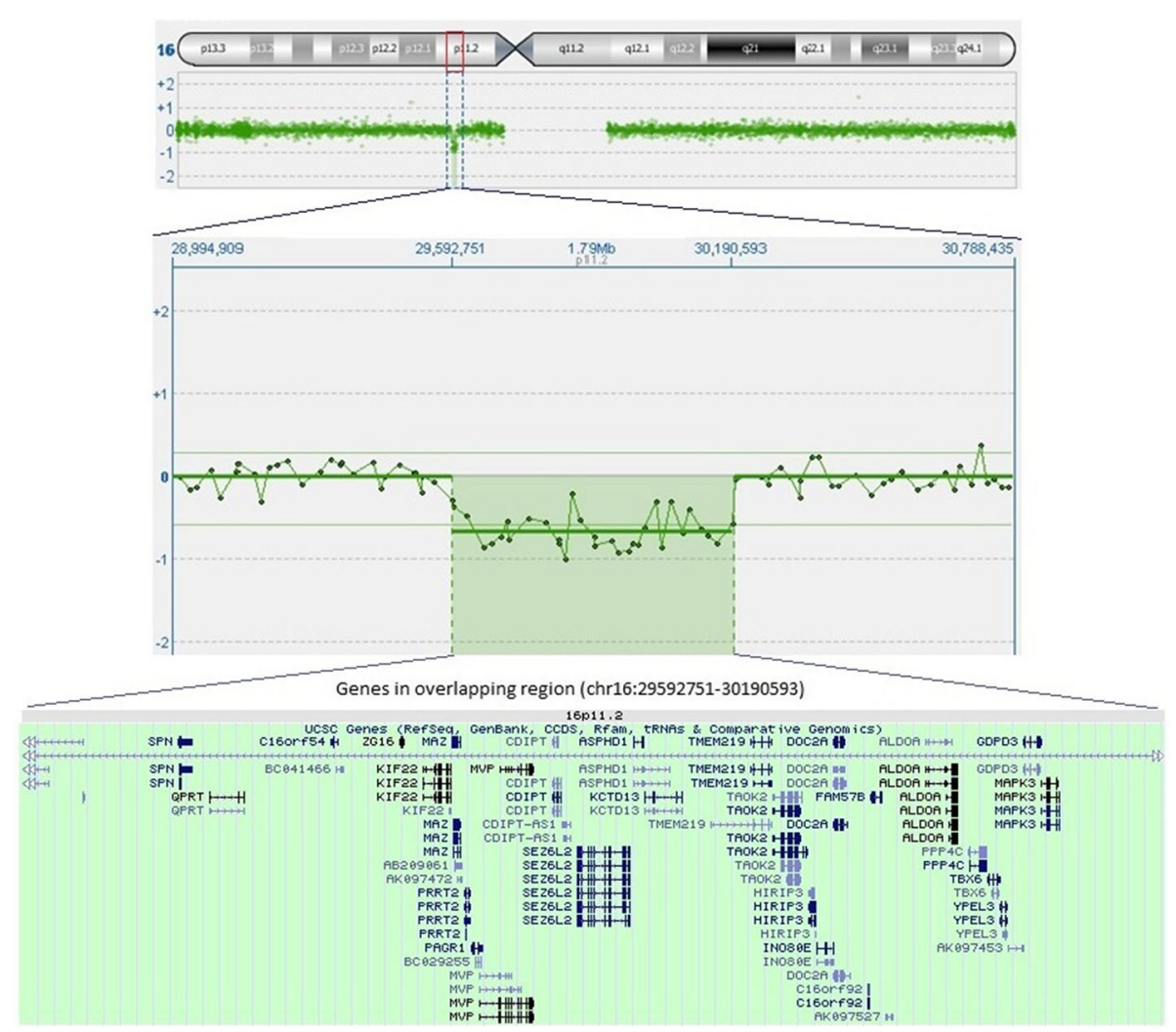

Fig. 2 Chromosome 16p11.2 deletion in our patient. The top panel shows the ideogram of chromosome 16 with the 16p1 1.2 (29592751-30,190,593) deleted region marked in a small red box. The scatter plot of the array-comparative genomic hybridization data, in the central panel, shows a $597.84 \mathrm{~kb}$ microdeletion of 16p11.2 in our patient. The University of California, Santa Cruz (GRCh37/hg19 assembly) genes in the overlapping region are shown in the bottom panel 
CDIPT, DOC2A, FAM57B, GDPD3, HIRIP3, KCTD13, KIF22, MAPK3, MAZ, MVP, PAGR1, PPP4C, PRRT2, QPRT, SEZ6L2, SPN, TAOK2, TBX6, YPEL3 and ZG16.

To verify if the observed microdeletion was a de novo mutation or has been inherited from parents, a CGH array on parental samples was performed. The analysis highlighted that the proband's mother presented the same microdeletion as the daughter.

\section{Methods}

\section{Cytogenetic analysis}

Peripheral blood samples obtained from the proband and her parents were cultured for 72 hours in RPMI medium, supplemented with $20 \%$ fetal calf serum and phytohemagglutinin.

Metaphase chromosomes were analyzed by standard G-banding using Wright's stain technique. None of the karyotypes exhibited cytogenetic alterations.

\section{CGH array \\ DNA preparation}

Genomic DNA of the blood was obtained from the proband and her parents after obtaining signed informed consent. Genomic DNA was isolated from ethylenediaminetetraacetic acid (EDTA)-K3 peripheral blood lymphocytes by using a QIAamp DNA Mini Kit (Qiagen, Germany). DNA concentration and purity were determined with a NanoPhotometer P-Class (IMPLEN, Schatzbogen, Germany).

\section{CGH array}

Genomic DNA of a normal female control was obtained from Promega (cod: G1521). Array-based CGH analysis was performed using commercially available oligonucleotide microarrays containing approximately 180.00060 mer probes with an estimated average resolution of approximately $25 \mathrm{~Kb}$ from CytoSure ISCA v2 $180 \mathrm{~K}$, Oxford Gene Technology (OCT). DNA labeling was executed using the CytoSure Genomic DNA Labelling Kit (OGT, 020020). The amount of patient DNA and controls of the same sex used was $1 \mu \mathrm{g}$ in a final volume of $18 \mu \mathrm{l}$. Both DNAs were mixed with $10 \mu \mathrm{l}$ of Random primer and $10 \mu \mathrm{l}$ of Reaction Buffer to a total volume of $38 \mu \mathrm{l}$. The mix was denaturated at $99{ }^{\circ} \mathrm{C}$ for 20 minutes and then incubated in ice for 5 minutes. Each sample was added to $10 \mu \mathrm{l}$ of deoxycytidine triphosphate (dCTP) labeling mix, $1 \mu \mathrm{l}$ of Cy5-dCTP (test sample), $1 \mu \mathrm{l}$ of Cy3-dCTP (reference sample) and $1 \mu \mathrm{l}$ of Klenow and the mix was incubated at $37^{\circ} \mathrm{C}$ for 2 hours, at $65^{\circ} \mathrm{C}$ for 10 minutes, and then in ice for 5 minutes. Labeled samples were subsequently purified using purification columns (Amicon Ultra-0.5 mL). Labeling efficiency was determined using NanoPhotometer P330 (Implen). Each patient's dyelabeled DNA and reference DNA was combined with $5 \mu \mathrm{l}$ of Cot Human DNA (SureSeq OGT, 500,028), $11 \mu \mathrm{l}$ of 10X aCGH Blocking Agent, and $55 \mu$ l Agilent 2X HiRPM Hybridization Buffer (Agilent technologies, 5188-5220). These mixtures were denatured at $94{ }^{\circ} \mathrm{C}$ for 3 minutes, pre-incubated at $37{ }^{\circ} \mathrm{C}$ for 30 minutes, and hybridized to the array in a hybridization chamber (OGT, 800,030) for 22 hours at $65{ }^{\circ} \mathrm{C}$ in a rotating hybridization $(\mathrm{Hyb})$ oven at 20 revolutions per minute (rpm; OGT, 800,010). Arrays were washed using Agilent Oligo CGH Wash Buffer 1 and 2 (Agilent 5188-5221 and 5188-5222), Acetonitryl (Sigma-Aldrich, 271,004-1 L), and Stabilisation and Drying Solution (Agilent, 5185-5979), according to the Wash Procedure in OGT's protocol.

The slide was scanned using an InnoScan 710 Microarray Scanner (Innopsys) with a resolution of $3 \mu \mathrm{m}$. Data were extracted from the microarray image, the background subtracted, and then normalized using feature extraction software Mapix 8.1.1. These data were subsequently imported into CytoSure Interpret Software v. 4.8 (OGT-020022). The genomic copy number was defined by the analysis of the normalized $\log 2(\mathrm{Cy} 5 / \mathrm{Cy} 3)$ ratio average of the $\mathrm{CGH}$ signal. The moving average was computed using four consecutive probes. Regions that reached a threshold $>0.3$ were interpreted as a duplication, whereas thresholds $\leq 0.6$ were interpreted as a deletion. Genomic region analyses were performed according to the human reference sequence build 37 .

\section{Copy number variations (CNVs) validation}

CNVs were compared to the DECIPHER, DGV, International Standard for Cytogenomic Arrays (ISCA) consortium (https://www.iscaconsortium.org/index.php/search), and Troina Database of Human CNVs (http://gvarianti.homelinux.net/gvariantib37/index.php) and classified pathogenic, likely pathogenic, benign, likely benign, or of unknown significance, using the following criteria:

- pathogenic - anomalies mapping on genomic regions associated to known syndromes or involving known dosage-sensitive genes and large imbalances of de novo origin or inherited from a similarly affected parent;

- likely pathogenic - small alterations of de novo origin or inherited from a parent with a similar phenotype, involving genomic regions or genes whose possible association with clinical conditions has not been definitely identified, but could be supposed from the clinical databases (DECIPHER, ISCA and Troina);

- benign - polymorphic variants reported in several healthy individuals in more than one study within DGV and/or alterations detected in at least two patients with clearly distinct phenotypes of the present cohort; 
- likely benign - microdeletions and microduplications reported in few controls in DGV, but defined benign or likely benign in the clinical databases (DECIPHER, ISCA, and Troina) and inherited from a normal parent;

- of unknown significance - inherited alterations not described or with discordant definitions among those databases [17].

\section{Fluorescence in situ hybridization (FISH) analysis}

To confirm the CGH array results, FISH analysis was performed by means of specific commercial probes (Abbott Laboratories, Abbott Park, Illinois, USA; Vysis probe name, LSI FUS (Cen); Spectrum Orange Probe $275 \mathrm{~Kb})$. FISH confirmed the presence of $16 \mathrm{p} 11.2$ microdeletion both in the proband and in her mother.

\section{Conclusions}

The case described in this case report is worthy of note because the observed microdeletion is almost always associated with a clinical phenotype tending to overweightness; however, the proband was hospitalized because she was underweight, of short stature and anorexic. Moreover, the observed genomic abnormality has a segregant nature. A phenotypical variability between mother and daughter has been found.

The case described here enriches the phenotypical spectrum linked to the 16p11.2 microdeletion. For these reasons, if a genetic pathology is suspected, it is fundamental to study the proband from the clinical point of view, to extend the clinical examination to her parents, and to provide a good family anamnesis. It is also essential that a multidisciplinary team carefully evaluates the patient.

In this way it is possible to highlight the presence of a genetic pathology with variable expressivity. 16p11.2 microdeletion is inherited in an autosomal dominant manner. The proband often has a de novo deletion; however, as in this case, the deletion can also be transmitted from a parent to a child. Interpretation of results from prenatal testing is challenging given the inherent difficulty in accurately predicting the phenotype.

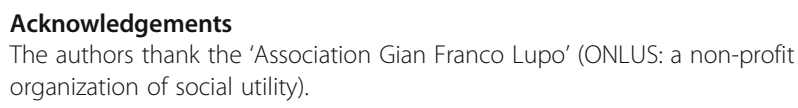

\section{Funding}

Not applicable.

Availability of data and materials

Not applicable.

\section{Authors' contributions}

$\mathrm{DD}, \mathrm{RD}$, and $\mathrm{CD}$ took the history and performed the physical examination. $\mathrm{CD}$ and $\mathrm{RD}$ participated in patient care. $\mathrm{DD}, \mathrm{AA}, \mathrm{FS}, \mathrm{MGL}$, and $\mathrm{CL}$ performed all laboratory tests. DD wrote the initial draft of the manuscript. All authors reviewed and contributed to the final version of this case report. All authors read and approved the final manuscript.
Ethics approval and consent to participate

Ethical clearance was sought from the Directorate of Research of the Ethical Committee Basilicata Region (Italy).

\section{Consent for publication}

Written informed consent was obtained from the patient's legal guardian(s) for publication of this case report and any accompanying images. A copy of the written consent is available for review by the Editor-in-Chief of this journal.

\section{Competing interests}

The authors declare that they have no competing interests.

\section{Publisher's Note}

Springer Nature remains neutral with regard to jurisdictional claims in published maps and institutional affiliations.

\section{Author details}

'Unit of Cytogenetic and Molecular Genetics, "Madonna delle Grazie" Hospital, 75100 Matera, Italy. ${ }^{2}$ Unit of Neonatology and Pediatrics, "Madonna delle Grazie" Hospital, Matera, Italy. ${ }^{3}$ Department of Pharmaceutical Sciences, University of Padua, Padua, Italy.

Received: 3 November 2017 Accepted: 28 January 2018

Published online: 03 April 2018

\section{References}

1. Bassuk AG, Geraghty E, Wu S, Mullen SA, Berkovic SF, Scheffer IE, Mefford HC. Deletions of 16p11.2 19p13.2 in a family with intellectual disability and generalized epilepsy. Am J Med Genet A. 2013;161A(7):1722-5.

2. Jacquemont S, Reymond A, Zufferey F, Harewood L, Walters RG, Kutalik Z, Martinet D, Shen Y, Valsesia A, Beckmann ND, Thorleifsson G, Belfiore M, Bouquillon S, Campion D, de Leeuw N, de Vries BB, Esko T, Fernandez BA, Fernandez-Aranda F, Fernandez-Real JM, Gratacos M, Guilmatre A, Hoyer J, Jarvelin MR, Kooy RF, Kurg A, Le Caignec C, Mannik K, Platt OS, Sanlaville D, Van Haelst MM, Villatoro Gomez S, Walha F, Wu BL, Yu Y, Aboura A, Addor MC, Alembik Y, Antonarakis SE, Arveiler B, Barth M, Bednarek N, Bena F, Bergmann S, Beri M, Bernardini L, Blaumeiser B, Bonneau D, Bottani A, Boute O, Brunner HG, Cailley D, Callier P, Chiesa J, Chrast J, Coin L, Coutton C, Cuisset JM, Cuvellier JC, David A, de Freminville B, Delobel B, Delrue MA, Demeer B, Descamps D, Didelot G, Dieterich K, Disciglio V, Doco-Fenzy M, Drunat S, Duban-Bedu B, Dubourg C, El-Sayed Moustafa JS, Elliott P, Faas BH, Faivre L, Faudet A, Fellmann F, Ferrarini A, Fisher R, Flori E, Forer L, Gaillard D, Gerard M, Gieger C, Gimelli S, Gimelli G, Grabe HJ, Guichet A, Guillin O, Hartikainen AL, Heron D, Hippolyte L, Holder M, Homuth G, Isidor B, Jaillard S, Jaros Z, Jimenez-Murcia S, Helas GJ, Jonveaux P, Kaksonen S, Keren B, Kloss-Brandstatter A, Knoers NV, Koolen DA, Kroisel PM, Kronenberg F, Labalme A, Landais E, Lapi E, Layet V, Legallic S, Leheup B, Leube B, Lewis S, Lucas J, KD MD, Magnusson P, Marshall C, Mathieu-Dramard M, MI MC, Meitinger T, Mencarelli MA, Merla G, Moerman A, Mooser V, Morice-Picard F, Mucciolo M, Nauck M, Ndiaye NC, Nordgren A, Pasquier L, Petit F, Pfundt R, Plessis G, Rajcan-Separovic E, Ramelli GP, Rauch A, Ravazzolo R, Reis A, Renieri A, Richart C, Ried JS, Rieubland C, Roberts W, Roetzer KM, Rooryck C, Rossi M, Saemundsen E, Satre V, Schurmann C, Sigurdsson E, Stavropoulos DJ, Stefansson H, Tengstrom C, Thorsteinsdottir U, Tinahones FJ, Touraine R, Vallee L, van Binsbergen E, Van der Aa N, Vincent-Delorme C, Visvikis-Siest S, Vollenweider P, Volzke H, Vulto-van Silfhout AT, Waeber G, WallgrenPettersson C, Witwicki RM, Zwolinksi S, Andrieux J, Estivill X, Gusella JF, Gustafsson O, Metspalu A, Scherer SW, Stefansson K, Blakemore Al, Beckmann JS, Froguel P. Mirror extreme BMI phenotypes associated with gene dosage at the chromosome 16p11.2 locus. Nature. 2011;478:97-102.

3. Walsh KM, Bracken MB. Copy number variation in the dosage-sensitive $16 p 11.2$ interval accounts for only a small proportion of autism incidence: a systematic review and meta-analysis. Genet Med. 2011;13:377-84.

4. Kumar RA, KaraMohamed S, Sudi J, Conrad DF, Brune C, Badner JA, Gilliam TC, Nowak NJ, Cook EH Jr, Dobyns WB, Christian SL. Recurrent 16p11.2 microdeletions in autism. Hum Mol Genet. 2008;17:628-38.

5. Marshall CR, Noor A, Vincent JB, Lionel AC, Feuk L, Skaug J, Shago M, Moessner R, Pinto D, Ren Y, Thiruvahindrapduram B, Fiebig A, Schreiber S, Friedman J, Ketelaars CE, Vos YJ, Ficicioglu C, Kirkpatrick S, Nicolson R, Sloman L, Summers A, Gibbons CA, Teebi A, Chitayat D, Weksberg R, Thompson A, Vardy C, Crosbie V, Luscombe S, Baatjes R, Zwaigenbaum L, Roberts W, Fernandez B, Szatmari P, 
Scherer SW. Structural variation of chromosomes in autism spectrum disorder. Am J Hum Genet. 2008:82:477-88.

6. Sebat J, Lakshmi B, Malhotra D, Troge J, Lese-Martin C, Walsh T, Yamrom B, Yoon S, Krasnitz A, Kendall J, Leotta A, Pai D, Zhang R, Lee YH, Hicks J Spence SJ, Lee AT, Puura K, Lehtimaki T, Ledbetter D, Gregersen PK, Bregman J, Sutcliffe JS, Jobanputra V, Chung W, Warburton D, King MC, Skuse D, Geschwind DH, Gilliam TC, Ye K, Wigler M. Strong association of de novo copy number mutations with autism. Science. 2007;316:445-9.

7. Weiss LA, Shen Y, Korn JM, Arking DE, Miller DT, Fossdal R, Saemundsen E, Stefansson H, Ferreira MA, Green T, Platt OS, Ruderfer DM, Walsh CA, Altshuler D, Chakravarti A, Tanzi RE, Stefansson K, Santangelo SL, Gusella JF, Sklar P, Wu BL, Daly MJ. Association between microdeletion and microduplication at 16p11.2 and autism. N Engl J Med. 2008:358:667-75.

8. Sanders SJ, Ercan-Sencicek AG, Hus V, Luo R, Murtha MT, Moreno-De-Luca D, Chu SH, Moreau MP, Gupta AR, Thomson SA, Mason CE, Bilguvar K, Celestino-Soper PB, Choi M, Crawford EL, Davis L, Wright NR, Dhodapkar RM, DiCola M, DiLullo NM, Fernandez TV, Fielding-Singh V, Fishman DO, Frahm S, Garagaloyan R, Goh GS, Kammela S, Klei L, Lowe JK, Lund SC, McGrew AD, Meyer KA, Moffat WJ, Murdoch JD, O'Roak BJ, Ober GT, Pottenger RS, Raubeson MJ, Song Y, Wang Q, Yaspan BL, Yu TW, Yurkiewicz IR, Beaudet AL, Cantor RM, Curland M, Grice DE, Gunel M, Lifton RP, Mane SM, Martin DM, Shaw CA, Sheldon M, Tischfield JA, Walsh CA, Morrow EM, Ledbetter DH, Fombonne E, Lord C, Martin CL, Brooks Al, Sutcliffe JS, Cook EH Jr, Geschwind D, Roeder K, Devlin B, State MW. Multiple recurrent de novo CNVs, including duplications of the 7q11.23 Williams syndrome region, are strongly associated with autism. Neuron. 2011;70:863-85.

9. Bochukova EG, Huang N, Keogh J, Henning E, Purmann C, Blaszczyk K, Saeed S, Hamilton-Shield J, Clayton-Smith J, O'Rahilly S, Hurles ME, Farooqi IS. Large, rare chromosomal deletions associated with severe early-onset obesity. Nature. 2010;463:666-70.

10. Tabet AC, Pilorge M, Delorme R, Amsellem F, Pinard JM, Leboyer M, Verloes A, Benzacken B, Betancur C. Autism multiplex family with 16p11.2p12.2 microduplication syndrome in monozygotic twins and distal 16p11.2 deletion in their brother. Eur J Hum Genet. 2012;20(5):540-6.

11. Miller DT, Chung W, Nasir R, Shen Y, Steinman KJ, Wu BL, Hanson E. 16p11.2 Recurrent Microdeletion. In: Pagon RA, Adam MP, Ardinger HH, Wallace SE, Amemiya A, LJH B, Bird TD, Ledbetter N, Mefford HC, RJH S, Stephens K, editors. GeneReviews ${ }^{\oplus}$ [Internet]. Seattle: University of Washington, Seattle; 2009. p. 1993-20170. [updated 2015 Dec 10].

12. Fernandez BA, Roberts W, Chung B, Weksberg R, Meyn S, Szatmari P, Joseph-George AM, Mackay S, Whitten K, Noble B, Vardy C, Crosbie V, Luscombe S, Tucker E, Turner L, Marshall CR, Scherer SW. Phenotypic spectrum associated with de novo and inherited deletions and duplications at 16p11.2 in individuals ascertained for diagnosis of autism spectrum disorder. J Med Genet. 2010:47:195-203.

13. Moreno-De-Luca A, Evans DW, Boomer KB, Hanson E, Bernier R, Goin-Kochel RP, Myers SM, Challman TD, Moreno-De-Luca D, Slane MM, et al. The role of parental cognitive, behavioral, and motor profiles in clinical variability in individuals with chromosome 16p11.2 deletions. JAMA Psychiat. 2015;72:119-26.

14. Maillard AM, Ruef A, Pizzagalli F, Migliavacca E, Hippolyte L, Adaszewski S, Dukart J, Ferrari C, Conus P, Männik K, et al. The 16p11.2 locus modulates brain structures common to autism, schizophrenia and obesity. Mol Psychiatry. 2015;20:140-7.

15. Walters RG, Jacquemont $S$, Valsesia A, de Smith AJ, Martinet D, Andersson J, Falchi M, Chen F, Andrieux J, Lobbens S, Delobel B, Stutzmann F, ElSayedMoustafa JS, Chèvre JC, Lecoeur C, Vatin V, Bouquillon S, Buxton JL, Boute $\mathrm{O}$, Holder-Espinasse M, Cuisset JM, Lemaitre MP, Ambresin AE, Brioschi A, Gaillard M, Giusti V, Fellmann F, Ferrarini A, Hadjikhani N, Campion D, Guilmatre A, Goldenberg A, Calmels N, Mandel JL, Le Caignec C, David A, Isidor B, Cordier MP, Dupuis-Girod S, Labalme A, Sanlaville D, Béri-Dexheimer M, Jonveaux P, Leheup B, Ounap K, Bochukova EG, Henning E, Keogh J, Ellis RJ, Macdermot KD, van Haelst MM, Vincent-Delorme C, Plessis G, Touraine R, Philippe A, Malan V, Mathieu-Dramard M, Chiesa J, Blaumeiser B, Kooy RF, Caiazzo R, Pigeyre M, Balkau B, Sladek R, Bergmann S, Mooser V, Waterworth D, Reymond A, Vollenweider P, Waeber G, Kurg A, Palta P, Esko T, Metspalu A, Nelis M, Elliott P, Hartikainen AL, MI MC, Peltonen L, Carlsson L, Jacobson P, Sjöström L, Huang N, Hurles ME, O'Rahilly S, Faroogi IS, Männik K, Jarvelin MR, Pattou F, Meyre D, Walley AJ, Coin $L$, Blakemore Al, Froguel P, Beckmann JS. A new highly penetrant form of obesity due to deletions on chromosome 16p11.2. Nature. 2010; 463(7281):671-5.
16. Maillard AM, Hippolyte L, Rodriguez-Herreros B, Chawner SJ, Dremmel D, Agüera Z, Fagundo AB, Pain A, Martin-Brevet S, Hilbert A, Kurz S, Etienne R, Draganski B, Jimenez-Murcia S, Männik K, Metspalu A, Reigo A, Isidor B, Le Caignec C, David A, Mignot C, Keren B; 16p11.2 European Consortium, van den Bree MB, Munsch S, Fernandez-Aranda F, Beckmann JS, Reymond A, Jacquemont S. 16p11.2 Locus modulates response to satiety before the onset of obesity. Int J Obes (Lond). 2016;40(5):870-6.

17. Kearney HM, Thorland EC, Brown KK, Quintero-Rivera F, South ST, Working Group of the American College of Medical Genetics Laboratory Quality Assurance Committee. American College of Medical Genetics standards and guidelines for interpretation and reporting of postnatal constitutional copy number variants. Genet Med. 2011;13(7):680-5.

\section{Submit your next manuscript to BioMed Central and we will help you at every step:}

- We accept pre-submission inquiries

- Our selector tool helps you to find the most relevant journal

- We provide round the clock customer support

- Convenient online submission

- Thorough peer review

- Inclusion in PubMed and all major indexing services

- Maximum visibility for your research

Submit your manuscript at www.biomedcentral.com/submit
C Biomed Central 